\title{
HUBUNGAN PENGETAHUAN DAN SIKAP REMAJA PUTRI TENTANG ANEMIA DENGAN PERILAKU MENGKONSUMSI TABLET ZAT BESI DI RW 12 GENENGAN MOJOSONGO JEBRES SURAKARTA
}

\author{
Relationship Of Knowledge And Attitude Of Adolescent Girls About Anemia With \\ Behavior Consumption Of Iron Tablets In Rw 12 Genengan \\ Mojosongo Jebres Surakarta
}

Etik Sulistyorini ${ }^{1}$, Siti Maesaroh ${ }^{2}$

Stikes Mamba'ul 'Ulum Surakarta

(etik_sulistyorini@yahoo.co.id)

\begin{abstract}
ABSTRAK
Latar Belakang : Anemia masih merupakan masalah kesehatan di Indonesia yang belum tuntas ditangani. Prevalensi kejadian anemia pada remaja putri di Indonesia masih tinggi, yaitu sebesar $22,7 \%$. Salah satu program pemerintah untuk pencegahan anemia dan peningkatan cadangan zat besi dalam tubuh adalah melalui program pemberian tablet zat besi pada remaja putri dengan frekwensi pemberian 1 (satu) tablet per minggu sepanjang tahun. Namun demikian, belum semua remaja putri telah mengkonsumsi tablet zat besi sesuai program tersebut. Banyak faktor yang menyebabkan remaja putri tidak rutin dan patuh dalam mengkonsumsi tablet zat besi.

Tujuan : Penelitian ini bertujuan untuk mengetahui apakah ada hubungan antara pengetahuan dan sikap remaja putri tentang anemia dengan perilaku dalam mengkonsumsi tablet zat besi.
\end{abstract}

Metode : Penelitian ini merupakan penelitian survey analitik dengan pendekatan cross sectional. Populasi dalam penelitian ini adalah seluruh remaja putri yang ada di RW 12 Genengan Mojosongo Jebres Surakarta yang berjumlah 146 orang. Tehnik pengambilan sampel menggunakan accidental sampling didapatkan jumlah responden 58 orang. Alat Pengumpulan data menggunakan kuesioner dengan skala Guttman dan Likert. Analisa data menggunakan korelasi Kendall Tau.

Hasil : Pengetahuan remaja putri tentang anemia mayoritas dalam kategori cukup sebanyak 40 responden (69\%). Sikap remaja putri tentang anemia mayoritas dalam kategori cukup sebanyak 42 responden $(72,4 \%)$. Perilaku remaja putri dalam mengkonsumsi tablet zat bezi mayoritas dalam kategori kurang sebanyak 30 responden $(51,7 \%)$. Hasil koefisien korelasi Kendall Tau sebesar 0,022 dengan angka signifikansi sebesar 0,855 sehingga tidak ada hubungan antara pengetahuan remaja putri tentang anemia dengan perilaku mengkonsumsi tablet zat besi. Hasil koefisien korelasi Kendall Tau sebesar -0,181 dengan angka signifikansi sebesar 0,155 sehingga tidak ada hubungan antara sikap remaja putri tentang anemia dengan perilaku mengkonsumsi tablet zat besi.

Simpulan : Tidak ada hubungan antara pengetahuan dan sikap remaja putri tentang anemia dengan perilaku mengkonsumsi tablet zat besi di RW 12 Genengan Mojosongo Jebres Surakarta.

Kata Kunci : Pengetahuan, Sikap, Perilaku, Remaja Putri, Anemia, Tablet Zat Besi 


\begin{abstract}
Background: Anemia is still a health problem in Indonesia that has not been fully handled yet. The prevalence of anemia in adolescent girls in Indonesia is still high, amounting to $22.7 \%$. One government program for the prevention of anemia and an increase in iron reserves in the body is through the program of administering iron tablets to adolescent girls with the frequency of giving 1 (one) tablet per week throughout the year. However, not all adolescent girl have consumed iron tablets according to the program. Many factors cause adolescent girls to be irregular and obedient in consuming iron tablets.

Objective: This study aimed to determine whether there was a relationship between the knowledge and attitudes of adolescent girls about anemia and behavior in consuming iron tablets.

Method: This study was an analytical survey research with a cross sectional approach. The population in this study were all adolescent girls in RW 12 Genengan Mojosongo Jebres Surakarta, totaling 146 people. The sampling technique using accidental sampling obtained the number of respondents 58 people. Data collection tool applied a questionnaire with a Guttman and Likert scale. The data analyzed used the Kendall Tau correlation.

Results: Knowledge of adolescent girls about anemia in the majority of the categories was 40 respondents (69\%). The attitude of adolescent girls about anemia in the majority in the adequate category was 42 respondents $(72.4 \%)$. The behavior of adolescent girls in consuming the majority of iron tablets in the less category was 30 respondents $(51.7 \%)$. The results of the Kendall Tau correlation coefficient of 0.022 with a significance number of 0.855 so that there was no relationship between the knowledge of adolescent girls about anemia with the behavior of consuming iron tablets. The results of the Kendall Tau correlation coefficient of -0.181 with a significance number of 0.155 so that there was no relationship between the attitudes of adolescent girls about anemia with the behavior of consuming iron tablets.

Conclusion: There is no relationship between the knowledge and attitudes of adolescent girls about anemia with the behavior of consuming iron tablets in RW 12 Genengan Mojosongo Jebres Surakarta.
\end{abstract}

Keywords: Knowledge, Attitude, Behavior, Adolescent Girls, Anemia, Iron Tablets

\title{
PENDAHULUAN
}

Anemia masih merupakan masalah kesehatan di Indonesia yang belum tuntas ditangani. Prevalensi kejadian anemia pada remaja perempuan di Indonesia masih tinggi, yaitu sebesar $22,7 \%$. Anemia pada remaja dapat berdampak jangka panjang bagi dirinya maupun anaknya kelak. Remaja yang menderita anemia bisa mengembangkan anemia yang lebih parah saat hamil karena kebutuhan gizi saat hamil mengalami peningkatan. Jika tidak segera diatasi, maka dapat membahayakan dirinya dan bayinya. (Veratemala A, 2017) Hasil Riset Kesehatan 
Daerah (Riskesdas) 2018 menunjukan peningkatan prevalensi anemia pada ibu hamil yaitu 37,1\% pada tahun 2013 menjadi 48,9\% pada tahun 2018. Hal ini tidak terlepas dari peran konsumsi gizi pada masa remaja sehingga berdampak pada status gizi dan anemia pada masa kehamilannya. (Kemenkes RI, 2018)

Masa remaja merupakan masa di mana pertumbuhan terjadi dengan cepat, sehingga kebutuhan gizi pada masa ini pun ikut meningkat. Salah satu zat gizi yang kebutuhannya meningkat adalah zat besi. Zat besi dibutuhkan pada semua sel tubuh dan merupakan dasar dalam proses fisiologis, seperti pembentukan hemoglobin (sel darah merah) dan fungsi enzim. Perempuan membutuhkan asupan zat gizi yang lebih tinggi dibandingkan laki-laki. Tabel Angka Kecukupan Gizi (AKG) mengatakan bahwa kebutuhan zat besi remaja perempuan usia 13-29 tahun adalah $26 \mathrm{mg}$, angka ini jauh lebih tinggi bila dibandingkan laki-laki seusianya. Pada perempuan, asupan zat besi tidak hanya digunakan untuk mendukung pertumbuhan, tetapi juga digunakan untuk mengganti zat besinya yang hilang melalui darah yang keluar setiap mengalami menstruasi setiap bulannya. Karena kebutuhan zat besi perempuan yang sangat tinggi inilah, perempuan berisiko mengalami kekurangan zat besi, yang nantinya dapat berkembang menjadi anemia. (Veratemala A, 2017)

Anemia pada remaja perempuan dapat berdampak panjang untuk dirinya dan juga untuk anaknya yang dia lahirkan kelak. Dampak anemia kemungkinan tidak langsung terlihat, namun dapat berlangsung lama dan mempengaruhi kehidupan remaja selanjutnya. Ada beberapa faktor resiko yang menyebabkan remaja mengalami anemia, diantaranya adalah : pertumbuhan yang cepat, ketidakcukupan asupan makanan zat bezi atau makanan sumber vitamin C, melakukan diet vegetarian, melakukan diet yang membatasi asupan kalori, sering melewatkan waktu makan, suka melakukan olahraga berat, dan kehilangan darah banyak saat menstruasi. Kondisi - kondisi tersebut dapat meningkatkan resiko anemia pada remaja dan memberikan dampak berupa : terganggunya pertumbuhan dan perkembangan, kelelahan, kerentanan terhadap infeksi karena sistem kekebalan tubuh menurun, menurunkan fungsi daya tahan tubuh, rentan terjadi keracunan, dan terganggunya fungsi kognitif. (Veratemala A, 2017)

Siklus kehidupan perempuan untuk dapat berfungsi sesuai peran utamanya menjadi seorang ibu, dimulai sejak usia remaja. Oleh karena itu, perempuan harus senantiasa dalam keadaan sehat, termasuk didalamnya yaitu mempunyai status gizi sehat. Remaja yang sehat akan siap menjadi ibu yang sehat. Ibu yang sehat akan siap mengandung janin yang dapat tumbuh dan berkembang secara sehat dalam kandungan ibu, yang selanjutnya akan lahir sebagai bayi sehat dengan berat badan memadai. Seorang ibu yang sehat akan berhasil memberikan Air Susu Ibu (ASI) kepada bayinya sesuai anjuran badan kesehatan dunia (WHO) yaitu memberikan hanya ASI saja sampai bayi usia 6 bulan, dan tetap memberikan ASI sampai bayi usia 24 bulan. Selanjutnya, di usia tua perempuan akan tetap sehat, tidak terganggu oleh berbagai penyakit degeneratif yang dapat dicegah, seperti tekanan darah tinggi, diabetes mellitus, osteoporosis, jantung, dan lain sebagainya.(Bardosono, 2011)

Salah satu sasaran pokok Rencana Pembangunan Jangka Menengah Nasional (RPJMN) 2015 - 2019 adalah meningkatnya status kesehatan dan gizi 
anak, dimana tercantum didalamnya sasaran program gizi dan kesehatan ibu dan anak antara lain meningkatnya ketersediaan dan keterjangkauan pelayanan kesehatan yang bermutu bagi seluruh masyarakat. Indikator pembinaan perbaikan gizi masyarakat salah satunya adalah pemberian tablet zat besi bagi remaja putri dengan target sebesar 30\% pada tahun 2019. Maksud dan tujuan dari program tersebut adalah untuk meningkatkan status gizi remaja putri sehingga dapat memutus mata rantai terjadinya stunting, mencegah anemia dan meningkatkan cadangan zat besi dalam tubuh sebagai bekal dalam mempersiapkan generasi yang sehat berkualitas dan produktif. Program ini dilaksanakan melalui pemberian Tablet Tambah Darah (TTD) dengan komposisi $60 \mathrm{mg}$ zat besi elemental (dalam bentuk sediaan ferro sulfat, ferro fumarat atau ferro glukonat) dan 0,400 mg asam folat pada remaja putri usia 12 - 18 tahun di institusi pendidikan (SMP dan SMA atau yang sederajad) dan wanita usia subur usia 14-49 tahun di institusi tempat kerja dengan frekwensi pemberian 1 (satu) tablet per minggu sepanjang tahun. (Kemenkes RI, 2016)

Hasil Riskesdas 2018 menunjukkan bahwa proporsi remaja putri yang mendapatkan tablet zat besi adalah $76,2 \%$ sedangkan yang tidak mendapatkan tablet zat besi adalah $23,8 \%$. Namun demikian, dari $76,2 \%$ remaja putri yang mendapatkan tablet zat besi tersebut hanya ditemukan 1,4\% yang mengkonsumsi tablet zat besi $\geq 52$ butir, sedangkan 98,6 \% nya mengkonsumsi $<$ dari 52 butir.(Kemenkes RI, 2018) Penelitian lain menyebutkan bahwa program suplementasi zat besi pada remaja putri belum efektif, dimana hasil prevalensi anemia $(\mathrm{Hb}<12 \mathrm{gr} / \mathrm{dl})$ sebelum program 20,7 \% mengalami penurunan menjadi $15,2 \%$ setelah 4 bulan intervensi. (Permatasari, 2018) Data ini menunjukkan bahwa upaya yang telah dilakukan tersebut masih belum efektif untuk membudayakan remaja putri dalam mengkonsumsi tablet zat besi yang tentu saja akan berdampak pada belum efektifnya upaya untuk menurunkan kejadian anemia pada remaja putri di indonesia.

Berdasarkan hasil studi pendahuluan yang peneliti lakukan di RW 12 Genengan Mojosongo Jebres Surakarta didapatkan hasil bahwa dari 10 responden diketahui pengetahuannya tentang Anemia adalah Baik : $32 \%$, Cukup :44\%, Kurang: $24 \%$, yang memiliki sikap Baik ada: $9 \%$, Cukup: $49 \%$ dan Kurang: 42 $\%$. sedangkan yang memiliki perilaku dalam mengkonsumsi tablet zat besi sebagai upaya mencegah anemia yang Baik ada: $6 \%$, Cukup ada: $39 \%$ dan Kurang ada: $55 \%$. sehingga, berdasarkan data tersebut peneliti tertarik untuk meneliti secara lebih lanjut mengenai "Hubungan Pengetahuan Dan Sikap Remaja Putri Tentang Anemia Dengan Perilaku Mengkonsumsi Tablet Zat Besi Di RW 12 Genengan Mojosongo Jebres Surakarta”.

\section{METODE PENELITIAN}

Penelitian ini merupakan penelitian Survey Analitik dengan pendekatan Cross Sectional. Populasi dalam penelitian ini adalah seluruh remaja putri yang ada di RW 12 Genengan Mojosongo Jebres Surakarta yang berjumlah 146 orang. Tehnik pengambilan sampel menggunakan Accidental Sampling didapatkan jumlah responden 58 orang. Alat Pengumpulan data menggunakan kuesioner 
dengan skala Guttman (untuk kuesioner pengetahuan) dan skala Likert (untuk kuesioner sikap dan perilaku). Metode pengumpulan data menggunakan data primer dengan membagikan kuesioner pada remaja putri dan menggunakan data sekunder untuk melihat dokumen-dokumen atau catatan-catatan yang mendukung data penelitian. Analisa data menggunakan koerlasi Kendall Tau.

\section{HASIL DAN PEMBAHASAN}

Tabel 1 Distribusi Frekwensi Karakteristik Responden Berdasarkan Umur, dan Pendidikan.

\begin{tabular}{lcc}
\hline \multicolumn{1}{c}{ Karakteristik } & Frekwensi (f) & Prosentase (\%) \\
\hline Umur & & \\
Remaja Awal (12-16 tahun) & 27 & 46,6 \\
Remaja Akhir (17-25 tahun) & 31 & 53,4 \\
\hline Total & 58 & 100 \\
\hline Pendidikan & & \\
SD & 2 & 3,4 \\
SMP & 30 & 51,7 \\
SMA & 23 & 39,7 \\
PT & 3 & 5,2 \\
\hline Total & 58 & 100 \\
\hline
\end{tabular}

Berdasarkan Tabel 1 menunjukkan karakteristik umur responden mayoritas adalah umur 17 - 25 tahun (kategori remaja akhir). Menurut karakteristik pendidikan mayoritas adalah berpendidikan SMP yaitu 30 reponden $(51,7 \%)$.

Tabel 2 Distribusi Frekuensi Variabel Pengetahuan Remaja Putri tentang Anemia di RW 12 Genengan Mojosongo Jebres Surakarta

\begin{tabular}{ccc}
\hline Pengetahuan & Frekuensi (f) & Prosentase (\%) \\
\hline Baik & 12 & 20,7 \\
Cukup & 40 & 69,0 \\
Kurang & 6 & 10,3 \\
Total (n) & 58 & 100 \\
\hline
\end{tabular}

Tabel 2 diatas menunjukkan bahwa pengetahuan remaja putri tentang anemia mayoritas dalam kategori cukup yaitu sebanyak 40 responden (69 \%).

Tabel 3 Distribusi Frekuensi Variabel Sikap Remaja Putri tentang Anemia di RW 12 Genengan Mojosongo Jebres Surakarta.

\begin{tabular}{ccc}
\hline Sikap & Frekuensi (f) & Prosentase (\%) \\
\hline Baik & 16 & 27,6 \\
Cukup & 42 & 72,4 \\
Kurang & 0 & 0 \\
Total (n) & 58 & 100 \\
\hline
\end{tabular}


Tabel 3 diatas menunjukkan bahwa sikap remaja putri tentang anemia mayoritas dalam kategori cukup sebanyak 42 responden $(72,4 \%)$.

Tabel 4 Distribusi FrekuensiVariabel Perilaku Remaja Putri dalam Mengkonsumsi Tablet Zat Besi

\begin{tabular}{ccc}
\hline Perilaku & Frekuensi (f) & Prosentase (\%) \\
\hline Baik & 8 & 13,8 \\
Cukup & 20 & 34,5 \\
Kurang & 30 & 51,7 \\
Total (n) & 58 & 100 \\
\hline
\end{tabular}

Tabel 4 diatas menunjukkan bahwa perilaku remaja putri dalam mengkonsumsi tablet zat bezi mayoritas dalam kategori kurang sebanyak 30 responden $(51,7 \%)$.

Tabel 5 Tabulasi Silang Pengetahuan Remaja Putri tentang Anemia dengan Perilaku Remaja Putri dalam Mengkonsumsi Tablet Zat Besi.

\begin{tabular}{|c|c|c|c|c|c|c|c|c|}
\hline \multirow{2}{*}{ Pengetahuan } & \multicolumn{6}{|c|}{ Perilaku } & \multirow{2}{*}{ Total } & \multirow{2}{*}{$\%$} \\
\hline & Baik & $\%$ & Cukup & $\%$ & Kurang & $\%$ & & \\
\hline Baik & 0 & 0 & 6 & 10,3 & 6 & 10,3 & 12 & 20,6 \\
\hline Cukup & 8 & 13,8 & 12 & 20,7 & 20 & 34,5 & 40 & 69 \\
\hline Kurang & 0 & 0 & 2 & 3,5 & 4 & 6,9 & 6 & 10,4 \\
\hline Total & 8 & 13,8 & 20 & 34,5 & 30 & 51,7 & 58 & 100 \\
\hline
\end{tabular}

Berdasarkan Tabel 5 diketahui bahwa dari 12 reponden (20,6 \%) yang berpengetahuan baik tidak ada yang memiliki perilaku baik, ada 6 responden $(10,3 \%)$ yang memiliki perilaku cukup dan 6 responden $(10,3 \%)$ memiliki perilaku kurang. Dari 40 responden (69\%) yang berpengetahuan cukup terdapat 8 responden $(13,8 \%)$ yang memiliki perilaku baik, dan $20(34,5 \%)$ yang memiliki perilaku kurang. Dari 6 responden $(10,4 \%)$ yang berpengetahuan kurang tidak ada yang memiliki perilaku baik, ada 2 reponden $(3,5 \%)$ yang memiliki perilaku cukup, dan ada 4 responden $(6,9 \%)$ yang memiliki perilaku kurang.

Tabel 6 Hubungan Pengetahuan Remaja Putri Tentang Anemia dengan Perilaku dalam Mengkonsumsi Tablet Zat Besi.

\begin{tabular}{lllrr}
\hline \multicolumn{5}{c}{ Correlations } \\
\hline Kendall's tau_b & Pengetahuan & Correlation Coefficient & \multicolumn{1}{c}{$\begin{array}{c}\text { Perilaku } \\
\text { Remaja }\end{array}$} \\
& Remaja & Sig. (2-tailed) & 1.000 & .022 \\
& & $\mathrm{~N}$ &. & .855 \\
& Perilaku & Correlation Coefficient & .022 & 58 \\
& Remaja & Sig. (2-tailed) & .855 & .000 \\
& & $\mathrm{~N}$ & 58 & 58 \\
\hline
\end{tabular}


Pada Tabel 6 menunjukkan bahwa hasil koefisien korelasi Kendall Tau sebesar 0,022 dengan angka signifikansi sebesar 0,855. Penelitian ini menggunakan uji dua sisi (two tailed) dengan $\alpha=5 \%$, maka pada $\alpha=5 \%=0,05$ : $2=0,025$. Nilai signifikansi $0,855>0,025$, sehingga $\mathrm{H}_{0}$ diterima atau tidak ada hubungan antara pengetahuan remaja putri tentang anemia dengan perilaku mengkonsumsi tablet zat besi.

Tabel 7 Tabulasi Silang Sikap Remaja Putri Tentang Anemia dengan Perilaku Remaja Putri dalam Mengkonsumsi Tablet Zat Besi.

\begin{tabular}{lcccccccc}
\hline \multirow{2}{*}{ Sikap } & \multicolumn{9}{c}{ Perilaku } & & \multicolumn{2}{c}{ Total } & \multirow{2}{*}{$\%$} \\
& Baik & $\%$ & Cukup & $\%$ & Kurang & $\%$ & & \\
\hline Baik & 0 & 0 & 6 & 10,3 & 10 & 17,2 & 16 & 27,5 \\
Cukup & 8 & 13,8 & 14 & 24,2 & 20 & 34,5 & 42 & 72,5 \\
Kurang & 0 & 0 & 0 & 0 & 0 & 0 & 0 & 0 \\
Total & 8 & 13,8 & 20 & 34,5 & 30 & 51,7 & 58 & 100 \\
\hline
\end{tabular}

Berdasarkan tabel 7 diketahui bahwa dari 16 reponden $(27,5 \%)$ yang memiliki sikap baik tidak terdapat responden yang memiliki perilaku baik, ada 6 responden $(10,3 \%)$ yang memiliki perilaku cukup dan 10 responden $(17,2 \%)$ yang memiliki perilaku kurang. Dari 42 responden $(72,5 \%)$ yang memiliki sikap cukup terdapat 8 responden $(13,8 \%)$ yang memiliki perilaku baik, ada 14 responden $(24,2 \%)$ yang memiliki perilaku cukup, dan 20 reponden $(34,5 \%)$ yang memiliki perilaku kurang.

Tabel 8 Hubungan Sikap Remaja Putri Tentang Anemia dengan Perilaku dalam Mengkonsumsi Tablet Zat Bezi.

\begin{tabular}{|c|c|c|c|c|}
\hline \multicolumn{5}{|c|}{ Correlations } \\
\hline & & & Sikap Remaja & Perilaku Remaja \\
\hline \multirow{6}{*}{$\begin{array}{l}\text { Kendall's } \\
\text { tau_b }\end{array}$} & Sikap Remaja & Correlation Coefficient & 1.000 & -.181 \\
\hline & & Sig. (2-tailed) & . & .155 \\
\hline & & $\mathrm{N}$ & 58 & 58 \\
\hline & Perilaku Remaja & Correlation Coefficient & -.181 & 1.000 \\
\hline & & Sig. (2-tailed) & .155 & . \\
\hline & & $\mathrm{N}$ & 58 & 58 \\
\hline
\end{tabular}

Pada Tabel 8 menunjukkan bahwa hasil koefisien korelasi Kendall Tau sebesar -0,181 dengan angka signifikansi sebesar 0,155. Penelitian ini menggunakan uji dua sisi (two tailed) dengan $\alpha=5 \%$, maka pada $\alpha=5 \%=0,05$ : $2=0,025$. Nilai signifikansi $0,155>0,025$, sehingga $\mathrm{H}_{0}$ diterima atau tidak ada hubungan antara sikap remaja putri tentang anemia dengan perilaku mengkonsumsi tablet zat besi.

Hasil penelitian pada variabel pengetahuan (Tabel 2) menunjukkan bahwa pengetahuan remaja putri tentang anemia mayoritas dalam kategori cukup yaitu 40 responden (69 \%), sedangkan sebagian kecil memiliki kategori pengetahuan baik sebanyak 12 responden $(20,7 \%)$ dan pengetahuan kurang yaitu sebanyak 6 
responden (10,3\%). Dari semua responden yang memiliki pengetahuan baik memiliki latar belakang pendidika SMA (10 responden) dan PT (2 responden). Sedangkan responden yang berpendidikan SMP dan SD memiliki pengetahuan cukup dan kurang. Pengetahuan erat hubungannya dengan pendidikan, terutama pendidikan formal. Namun demikian, bukan berarti seseorang yang berpendidikan rendah mutlak berpengetahuan rendah pula. Seseorang yang memiliki pendidikan formal yang tinggi, diharapkan akan memiliki pengetahuan yang semakin luas. Peningkatan pengetahuan seseorang juga tidak mutlak didapatkan melalui pendidikan formal saja, melainkan juga dapat diperoleh melalui pendidikan non formal. Pendidikan diperlukan untuk mendapatkan informasi. Misalnya, informasi tentang kesehatan yang dapat digunakan untuk meningkatkan kualitas hidupnya. Pada umumnya semakin tinggi pendidikan seseorang semakin mudah menerima informasi. (Wawan, 2011). Pengetahuan juga dipengaruhi oleh umur. Hasil penelitian menunjukkan bahwa semua responden yang pengetahuannya baik berada pada kategori umur remaja akhir (17-25 tahun). Sedangkan remaja yang pengetahuannya kurang berada pada kategori umur remaja awal (12-16 Tahun). Masyarakat pada umumnya menilai bahwa seseorang yang lebih dewasa akan lebih dipercaya dibandingkan orang yang belum tinggi kedewasaannya, hal ini berkaitan dengan pengalaman dan kematangan jiwa seseorang tersebut. Semakin cukup umur, seseorang akan semakin lebih matang dalam berfikir dan bekerja. (Wawan, 2011).

Pada variabel sikap (Tabel 3) dapat dilihat bahwa sikap remaja putri tentang anemia mayoritas dalam kategori cukup sebanyak 42 responden $(72,4 \%)$ dan sebagian kecil mempunyai sikap yang baik sebanyak 16 responden $(27,6 \%)$. Dari 16 responden yang memiliki sikap baik, mayoritas berada pada kategori umur remaja akhir (17-25 tahun) yaitu sebanyak 13 responden, sedangkan yang berada pada kategori remaja awal (12-16 Tahun) hanya 3 responden. Semakin cukup umur, seseorang akan semakin lebih matang dalam berfikir dan bekerja. Namun, sikap merupakan kesiapan mental yaitu suatu proses yang berlangsung dalam diri seseorang bersama dengan pengalaman individual masing-masing, yang mengarahkan dan menentukan respon terhadap berbagai objek dan situasi. (Sarwono, 2011). Hasil penelitian ini juga menunjukkan dari 16 responden yang memiliki sikap baik, mayoritas berpendidikan SMA (8 responden), berpendidikan SMP ada 5 responden, dan berpendidikan PT ada 3 responden. Pendidikan dapat mempengaruhi seseorang termasuk mempengaruhi sikap dan perilaku seseorang untuk berperan serta dalam pembangunan kesehatan. Selain itu, sikap juga dipengaruhi oleh faktor lain, diantaranya adalah pengalaman pribadi, pengaruh orang lain yang dianggap penting, pengaruh kebudayaan, media massa, lembaga pendidikan dan faktor emosional. (Wawan, 2011). Masa remaja adalah terminologi yang digunakan untuk menyatakan periode pendewasaan pikiran dan tubuh sehingga dapat diterapkan kepada manusia sebelum, sesudah, dan selama pubertas. Selama masa remaja, terjadi perkembangan fisik, emosi, sosial, dan intelektual yang sangat cepat. Kemampuan menggunakan pikiran abstrak, sebagai lawan pola pikir konkret pada anak - anak, memungkinkan seorang remaja dapat menyelesaikan tugas - tugasnya. Hal tersebut membuat remaja dapat melakukan 
perencanaan dan menghubungkan fakta kedalam pikiran yang terintegrasi sehingga siap mengambil peranan dalam masyarakat dewasa. (Sayogo, 2012)

Pada variabel perilaku (Tabel 4) menunjukkan bahwa perilaku remaja putri dalam mengkonsumsi tablet zat bezi mayoritas dalam kategori kurang sebanyak 30 responden $(51,7 \%)$, perilaku dalam kategori cukup sebanyak 20 responden $(34,5 \%)$ dan perilaku dalam kategori baik sebanyak 8 responden $(13,8 \%)$. Hasil penelitian menunjukkan pada responden yang perilakunya kurang ada pada kategori umur yang bervariatif dan latar pendidikan yang bervariatif pula. Hal ini menunjukkan bahwa ada faktor lain yang lebih dominan dalam mempengaruhi perilaku seseorang. Perilaku dan gejala perilaku yang tampak pada kegiatan organisme dipengaruhi oleh faktor genetik (keturunan) dan lingkungan. Secara umum dapat dikatakan bahwa faktor genetik dan lingkungan ini merupakan penentu dari perilaku makhluk hidup termasuk perilaku manusia. Hereditas atau faktor keturunan adalah konsepsi dasar atau modal untuk perkembangan perilaku mahkluk hidup. Sedangkan lingkungan adalah suatu kondisi atau merupakan lahan untuk perkembangan perilaku tersebut. Tahap remaja menengah memiliki beberapa karakteristik yaitu sangat dipengaruhi oleh teman sebaya, kehilangan kepercayaan pada orang dewasa, mencoba mandiri dan sebagainya. Pada masa ini, remaja lebih mendengarkan teman sebayanya daripada orang tuanya atau orang dewasa lainnya. Keinginan untuk mandiri sering tampak dalam bentuk penolakan terhadap pola makan keluarga. Pada masa remaja lanjut karakteristik yang tampak antara lain merencanakan masa depan dan bersifat lebih mandiri serta mulai mempunya persepsi terhadap body image.(Sayogo, 2012)

Hasil penelitian pda tabulasi silang hubungan antara pengetahuan dengan perilaku (Tabel 5) menunjukkan bahwa remaja putri yang pengetahuannya baik ada 12 reponden $(20,6 \%)$, dan kesemuanya tidak ada yang memiliki perilaku baik, malah sebaiknya ada yang memiliki perilaku yang kurang yaitu ada 6 reponden $(10,3 \%)$, dan sisanya memiliki perilaku yang cukup. Hal ini menunjukkan bahwa pengetahuan bukanlah satu - satunya faktor yang dapat mempengaruhi perilaku seeorang. Faktor - faktor yang mempengaruhi terbentuknya perilaku dibedakan menjadi dua, yaitu : faktor internal dan faktor eksternal. Pengetahuan termasuk salah satu faktor internal yang mempengaruhi perilaku seseorang, disamping ada faktor lainnya yaitu kecerdasan, persepsi, emosi, dan motivasi. Sedangkan faktor eksternal meliputi lingkungan sekitar baik fisik maupun non fisik seperti iklim, manusia, sosial ekonomi, dan kebudayaan. (Wawan, 2011).

Hasil uji korelasi Kendall Tau menunjukkan koefisien korelasi sebesar 0,022 dengan angka signifikansi sebesar 0,855 sehingga $\mathrm{H}_{0}$ diterima atau tidak ada hubungan antara pengetahuan remaja putri tentang anemia dengan perilaku mengkonsumsi tablet zat besi. Pengetahuan merupakan domain yang sangat penting untuk terbentuknya tindakan seseorang (ovent behavior). Perilaku yang didasari oleh pengetahuan akan lebih langgeng daripada perilaku yang tidak didasari oleh pengetahuan.(Wawan, 2011). Dalam sebuah eksperimen menunjukkan bahwa pengetahuan tentang diri dapat mempengaruhi tindakan individu, dimana tingkah laku seseorang dipengaruhi oleh pengetahuan atau kesadaran tentang siapa dirinya.(Sarwono, 2011) Perilaku adalah respon individu 
terhadap suatu stimulus atau suatu tindakan yang dapat diamati dan mempunyai frekwensi spesifik, durasi, dan tujuan baik disadari maupun tidak. Perilaku dan gejala perilaku yang tampak pada kegiatan organisme dipengaruhi oleh faktor genetik (keturunan) dan lingkungan. (Sarwono, 2011).

Hasil penelitian ini sejalan dan mendukung penelitian sebelumnya pada remaja putri yang menunjukan hasil bahwa tidak teradapat hubungan antara pengetahuan dengan konsumsi tablet $\mathrm{Fe}$ dengan nilai $\mathrm{p}=0,321$.(Lestari $\mathrm{P}, 2015$ ) Penelitian lain yang dilakukan terhadap 1200 remaja putri di Bengkulu juga menunjukkan tidak ada hubungan antara pengetahuan tentang anemia dengan kejadian anemia $(p>0,05)$. Sebagian remaja memiliki pengetahuan yang baik terhadap hal - hal yang berhubungan dengan anemia, namun pengetahuan yang baik tersebut belum tentu mempengaruhi perilaku mereka dalam pemilihan makanan sehari-hari. Pengetahuan seseorang akan berpengaruh terhadap sikap dan perilaku dalam pemilihan makanan dan selanjutnya akan berpengaruh terhadap keadaan gizi seseorang (termasuk status anemia). Rendahnya pengetahuan remaja putri tentang anemia mengakibatkan kurangnya konsumsi makanan sumber protein hewani yang mengandung banyak zat besi. (Suryani, 2015).

Hasil penelitian tabulasi silang hubungan antara sikap dengan perilaku (Tabel 7 ) diketahui bahwa dari 16 reponden $(27,5 \%)$ yang memiliki sikap baik tidak terdapat responden yang memiliki perilaku baik, ada 6 responden $(10,3 \%)$ yang memiliki perilaku cukup dan 10 responden $(17,2 \%)$ yang memiliki perilaku kurang. Dari 42 responden $(72,5 \%)$ yang memiliki sikap cukup terdapat 8 responden $(13,8 \%)$ yang memiliki perilaku baik, ada 14 responden $(24,2 \%)$ yang memiliki perilaku cukup, dan 20 reponden $(34,5 \%)$ yang memiliki perilaku kurang. Hasil penelitian tersebut menunjukkan bahwa seseorang yang memiliki sikap baik belum tentu memiliki perilaku yang baik pula, begitu juga sebaliknya. Hal tersebut dapat terjadi karena sikap merupakan proses evaluasi yang sifatnya internal/subjektif yang berlangsung dalam diri seseorang dan tidak dapat diamati secara langsung. Sikap dapat diketahui melalui pengetahuan, keyakinan, perasaan, dan kecenderungan tingkah laku seseorang terhadap objek sikap.(Sarwono, 2011)

Hasil uji korelasi Kendall Tau (Tabel 8) menunjukkan koefisien korelasi sebesar -0,181 dengan angka signifikansi sebesar 0,155 sehingga $\mathrm{H}_{0}$ diterima atau tidak ada hubungan antara sikap remaja putri tentang anemia dengan perilaku mengkonsumsi tablet zat besi. Sikap dapat diposisikan sebagai hasil evaluasi terhadap objek yang diekspresikan kedalam proses kognitif, afektif, dan perilaku. Respon evaluatif dalam bentuk kognitif meliputi beliefs yang dimiliki individu terhadap objek sikap dengan berbagai atributnya. Respon evaluatif dalam bentuk afektif berupa perasaan individu terhadap objek sikap. Respon evaluatif dalam bentuk perilaku dapat berupa dukungan atau tindakan nyata yang dilakukan seseorang terhadap objek sikap. (Wawan, 2011)

Hasil penelitian ini mendukung dan sejalan dengan penelitian sebelumnya yang menunjukkan bahwa tidak terdapat hubungan antara sikap pencegahan anemia dan perilaku mengkonsumsi tablet tambah darah tidak mempengaruhi kadar $\mathrm{Hb}$ pada remaja putri dengan nilai $\mathrm{p}$ value masing-masing 0,154 dan 0,318. (Putri M.A, 2018). Penelitian yang lain juga menunjukkan bahwa tidak ada hubungan yang bermakna antara sikap dengan kepatuhan mengkonsumsi tablet $\mathrm{Fe}$ 
dengan nilai $p=0,501$. (Purnamasari G, 2016) Sikap terdiri dari tiga komponen yang intensitasnya dapat berbeda - beda pada masing - masing orang. Orang dengan sikap yang ekstrem, yaitu orang yang melibatkan intensitas perasaan yang sangat mendalam tentang suatu hal. Sikap dapat mempengaruhi perilaku, kuat lemahnya sikap bergantung pada ekstremitas dan pengalaman pribadi seseorang. Konsistensi hubungan sikap dan perilaku dipengaruhi oleh : kuat/lemahnya sikap yang dimiliki seseorang dan faktor situasional yang dapat menghambat seseorang untuk berperilaku sesuai dengan sikap yang dimilikinya.(Sarwono,2011).

\section{SIMPULAN DAN SARAN}

\section{Simpulan}

Pengetahuan remaja putri tentang anemia mayoritas dalam kategori cukup yaitu sebanyak 40 responden $(69 \%)$. Sikap remaja putri tentang anemia mayoritas dalam kategori cukup sebanyak 42 responden $(72,4 \%)$. Perilaku remaja putri dalam mengkonsumsi tablet zat bezi mayoritas dalam kategori kurang sebanyak 30 responden $(51,7 \%)$. Tidak ada hubungan antara pengetahuan remaja putri tentang anemia dengan perilaku mengkonsumsi tablet zat besi dengan hasil koefisien korelasi Kendall Tau sebesar 0,022 dengan angka signifikansi sebesar 0,855 . Tidak ada hubungan antara sikap remaja putri tentang anemia dengan perilaku mengkonsumsi tablet zat besi dengan hasil koefisien korelasi Kendall Tau sebesar -0,181 dengan angka signifikansi sebesar 0,155.

\section{Saran}

Bagi Remaja Putri diharapkan meningkatkan pengetahuan dan sikapnya tentang anemia, sehingga memiliki perilaku yang baik dalam mengkonsumsi tablet zat besi. Bagi Tenaga Kesehatan diharapkan dapat memotivasi remaja putri agar lebih rutin dalam mengkonsumsi tablet zat besi melalui kegiatan penyuluhan, pendampingan dan evaluasi atau pemantauan pada remaja putri dalam mengkonsumsi tablet zat besi sebagai upaya pencegahan anemia.

\section{DAFTAR PUSTAKA}

Bardosono, S 2011, Gizi Sehat Untuk Perempuan, Jakarta, Balai Penerbit Fakultas Kedokteran Universitas Indonesia.

Kementrian Kesehatan Republik Indonesia, 2018, Hasil Utama Riskesdas 2018, Jakarta, Badan Penelitian Dan Pengembangan Kesehetan Kemenkes RI.

Kementerian Kesehatan Republik Indonesia, 2016, Pedoman Pencegahan Dan Penanggulangan Anemia Pada Remaja Putri Dan Wanita Usia Subur (WUS), Jakarta, Direktorat Gizi Masyarakat Direktorat Jenderal Kesehatan Masyarakat Kemenkes RI.

Lestari. P, Widardo, Mulyani. S, 2015, Pengetahuan Berhubungan Dengan Konsumsi Tablet Fe Saat Menstruasi Pada Remaja Putri di SMA N 2 Banguntapan Bantul, Journal Ners And Midwifery Indonesia, Vol. 3 No. 3, Hal 145 - 149 
Permatasari, T, Briawan, D, \& Madanijah, S 2018, 'Efektifitas Program Suplementasi Zat Besi Pada Remaja Putri di Kota Bogor', Jurnal MKMI, Vol.14, No.1, Hal. 1 - 8.

Purnamasari G, 2016. Pengaruh Faktor Pengetahuan dan Sikap Terhadap Kepatuhan Ibu Hamil dalam mengkonsumsi Tablet Fe di Puskesmas Bogor Tengah. Jurnal Promosi Kesehatan Indonesia, Vol. 11 No. 2, Hal 100 - 116

Putri, MD, 2018, Hubungan Sikap Pencegahan Anemia Dan Perilaku Mengkonsumsi Tablet Tambah Darah Dengan Kadar Hemoglobin (Hb) Pada Remaja Putri di SMK N 1 Sukoharjo, Program Studi Ilmu Gizi Fakultas Ilmu Kesehatan, UMS. http://eprints.ums.ac.id/62647/, di akses tanggal 12 Desember 2018

Sarwono, S, Meinarno, E 2011, Psikologi Sosial, Jakarta, Salemba Humanika.

Sayogo, S 2012, Gizi Remaja Putri, Balai Penerbit Fakultas Kedokteran Universitas Indonesia.

Suryani, D 2015, 'Analisis Pola Makan dan Anemia Gizi Besi pada Remaja Putri Kota Bengkulu', Jurnal Kesehatan Masyarakat Andalas, Vol. 10, No. 1, hh. $11-18$.

Veratamala, A 2017, Kenapa Anemia Pada Remaja Perempuan Tidak Boleh Dibiarkan, Hello Sehat Medical Review Team, https://hellosehat.com/parenting/kesehatan-anak/anemia-pada-remajaperempuan-tak-boleh-dibiarkan/, dilihat 10 Desember 2018 